\title{
연구논문
}

\author{
산림경관의 시각적 관리등급 설정기법 현장적용 연구 \\ - 하이원 리조트 일대의 산림경관을 중심으로 - \\ 이관규·장효진 · 이민주 · 조현길 \\ 강원대학교 산림환경과학대학 조경학과 \\ (2012년 9월 17일 접수, 2012년 11월 19일 승인)
}

\section{A Study on Setting up Method for Visual Management of Forest Landscape and Field Application \\ - Focused on Forest Landscape around High One Resort in Jeongseon-gun, Gangwon-do -

\author{
Gwan-Gyu Lee · Hyo-Jin Jang · Min-Ju Lee · Hyun-Kil Jo
}

Department of Landscape Architecture, College of Forest Environment and Science, Kangwon National University

(Manuscript received 17 September 2012; accepted 19 November 2012)

\begin{abstract}
Since pursuing the pleasant life for people, there is an increase of desire to appreciate outstanding scenery with the difference in certain level for perception and understanding of human on landscaping, However, the quality of landscaping has become artificial with the pleasance to be declining due to the urbanization. This study was applied at the site around High One Resort area in Gohan-eup, Jeongseon-gun Gangwon-do for analyzing the areas sensitive to the landscaping change as well as degree of requirement for landscape management for forest landscape management with the focus on presenting the zoning method and the management class classification method. Even if the forest is the same, the function of it is different depending on land use or what resource is placed that the forestry function is found out to present the management plan for each forestry function in the subject site and the result of the management grade classification is analyzed in overlapping to the forestry function level. As a result, from the landscaping management requirement and visual absorption analysis, the result formulated for upper, middle and lower zones to classify the final forestry landscape management degree into 1-4 grades and the management plan is presented on the respective 14 grade area for each forestry function. By applying the technique to set the management grade, it was possible to formulate the result to provide the means for integrated management in
\end{abstract}

Corresponding Author: Hyun-Kil Jo. Dept. of Landscape Architecture, Kangwon National University, Chuncheon, 200-701, South Korea, Tel: +82-33-250-8345, E-mail: jhk@kangwon.ac.kr 
consideration of the forestry function and management of forestry landscape and resources.

Keywords : environmental planning, landscape planning, landscape design, forest, forest management

\section{1. 연구 배경}

경관에 대한 사람들의 지각과 이해의 정도 차이 는 다르나 일반적으로 우수한 경관을 감상하고자 하는 욕구도 증가하고 있지만(Karjalainen and Tyrvainen, 2002) 도시화로 인해 경관이 인공화되 고 쾌적성이 저하되고 있다(장철규 등, 2011). 우리 나라에서는 경관 관리와 관련하여 경관의 보전 및 창출을 위해 인간의 경관 인지도에 따른 경관 선호 도 연구(정윤희 등, 2002; 박민우와 송형섭, 2003; 김세천과 허준, 2007 ; 허준 등, 2007)나 경관평가 지표설정 연구(김승주와 임승빈, 2009; 강미희와 김성일, 2010 ; 김재준 등, 2010 ; 이관규, 2011 ; 이 관규와 박찬우, 2012) 등이 진행되었다.

외국에서도 경관과 관련하여 경관관리 기초자료 로써의 경관패턴연구, 시각적 선호도 연구, 질 평가 연구 등 다양한 연구를 해온 바 있다. 그 중 경관의 효율적이고 단계적인 관리를 위해 경관평가 연구 (Daniel and Boster, 1976; Ripple et al., 1991; Fry et al., 2009; Ode et al., 2009)가 국내보다 많았고 경관평가의 방법 중 하나로 GIS를 이용한 경관평가를 통해 우선적으로 관리가 필요한 곳을 선정하고 있었다(Germino et al., 2001; Yanar and Akyurek, 2006; Greene et al., 2010). 미 국, 캐나다, 호주의 경우, 산림경관관리를 위해 우 수한 산림경관이 내재된 지역이라면 산림 주변의 여건을 고려하면서도 산림경관보전과 창출을 최우 선적으로 하여 관리방향을 설정하고 있다(USDA Forest Service, 1973; 1974; 1995; British Columbia, 1981; 1996; 1997; Forestry Commission of Tasmania, 2006).

기본적으로 산림경관 관리를 위해 해당 구역을 어떠한 방향으로 관리할지 설정하기 위해 보전지역 구역구획, 경관관리가 집중적으로 필요한 지역, 경
관변화에 민감한 지역 등을 구획하여 관리할 필요 가 있다고 제기하였고(강미희와 김성일, 2010; 산 림청, 2011b; 이관규와 박찬우, 2012) 산림청에서 는 이와 관련된 지침을 마련하여 배포한 바 있다(산 림청, 2011b).

우리나라의 국토 약 $63.7 \%$ 는 산림으로 구성되어 있어서(산림청, 2011a) 도시나 농촌 등 어떤 지역에 가더라도 다양한 산림유형을 볼 수 있고 그에 따른 산림경관관리의 필요성이 대두되고 있다(산림청, 2011b). 산림은 지역자원 중 하나로 지역적 · 문화 적 배경에 따라 산림경관의 유형이나 산림자원의 쓰임이 달라질 수 있어서(산림청, 2011b) 산림유형 별 관리방향을 설정할 때 산림 주변의 토지이용이 나 지역적 배경을 고려한 경관관리가 필요하다는 의견도 제기되어 왔다. 국가는 이러한 추세를 따라 지속가능한 산림관리를 위해 2004년 '지속가능한 산림자원 관리지침' 을 제정하여 산림의 기능을 구 분한 바 있고(산림청, 2004), 경관의 중요성과 지침 마련을 위해 2007년에 경관법 제정하고 동법 제8 조 제 2 항에 근거한 '경관계획수립지침(행정안전부 등, 2009)' 을 발행한 바 있으며(산림청, 2011b) 최 근 2011년 '산림경관 계획 · 관리 업무편람' 을 발행 하면서 산림경관관리의 필요성과 구체적인 방안을 제시하였다. 산림경관에 대한 필요성 제기와 지침 발간이 최근에 이루어져 시행 초기단계이므로 체계 적 경관관리와 분석 틀이 필요하고, 산림자원이나 산림이 지닌 기능을 고려한 경관관리계획 수립의 모델이 필요한 상황이다.

본 연구는 산림경관관리를 위해 경관관리가 얼마 나 요구되는지와 경관변화에 민감한 지역을 분석하 여 관리의 등급을 구분함으로써 경관관리와 설계를 지원하는 방법적 모델을 제시하는데 중점을 두고 진행되었다. 또한, 산림이 지닌 다양한 특성을 고려 한 관리방안 제시를 위해 대상지 내 산림기능별 특 
성에 관리등급 구분 결과를 종합하여 산림기능별 관리방향을 제안하는 등 공간의사결정을 지원하는 데 목적을 두고 있다.

\section{Il. 연구 방법}

\section{1. 조망점 선정 방법}

Zube et al.(1982), Clay and Daniel(2000), Germino et al.(2001), Meitner(2004), Chang et al.(2011), 최윤과 조동범(1994), 김세천 등(1996), 구자훈(2001), 정정섭 등(2004), 조용준 등(2006), 방재성 등(2008), 이관규(2011), 장철규 등(2011)의 연구를 분석하고 조망점 선정을 위한 기법의 공통 항목을 도출한 결과, 대상지 내 주요 산림경관자원 을 조망하는 조망수요가 밀집된 지점을 조망점으로 선정한다는 결과를 도출할 수 있었고, 이를 토대로 본 연구에서는 조망점 선정 기준을 세 가지로 설정 하였다.

내업 및 현장답사를 통해 산림에서 주변을 잘 조 망할 수 있는 지점(정상이나 능선지점, 전망시설이 있는 지점 등), 산림경관자원 내부의 조망점(우세경 관자원이 잘 보이는 지점, 특이한 산림생태자원을 관찰 혹은 조망 가능한 지점), 주변에서 산림경관을 잘 조망하거나 조망기회가 우세한 지점(우세한 산 림경관자원 등이 보이기 시작하는 시점, 진입부, 이 용밀도가 높은 장소, 이용 및 통행빈도가 높은 주요 결절점)을 위주로 조망점을 선정하였다.

\section{2. 산림경관 관리 등급 설정 방법}

\section{(1) 산림경관 관리 등급 의사결정 체계 설정}

미국, 캐나다, 호주 등은 산림경관을 평가하여 등 급을 구분한 후 등급별 관리방안을 의사결정하고 있다. 미국 산림청(USDA FS, 1973; 1974; 1995) 은 산림경관을 시각적 민감도와 조망빈도 결과를 중첩하여 최종 등급을 도출하여 시각적으로 민감한 정도에 따라 보전(R), 부분적으로 보전(PR), 경관개 선 $(\mathrm{M})$, 매우 경관 개선 $(\mathrm{MM})$, 절대보존지역 $(\mathrm{P})$ 의 5
표 1. 의사결정 매트릭스 설정

\begin{tabular}{c|c|c|c|c}
\hline \hline \multicolumn{2}{c|}{} & \multicolumn{3}{|c}{ 시각적 민감도 } \\
\cline { 3 - 5 } \multicolumn{2}{c|}{} & 상 & 중 & 하 \\
\hline 경관 & 상 & 3등급 & 4등급 & 4등급 \\
\cline { 2 - 5 } 관리 & 중 & 2등급 & 3등급 & 4등급 \\
\cline { 2 - 5 } 요구도 & 하 & 1등급 & 2등급 & 3등급 \\
\hline \hline
\end{tabular}

개로 구분하고 있다. 호주 타즈매니아(Forestry Commission of Tasmania, 2006)의 경우에도 경 관관리요구도와 시각적 민감도 분석으로 최종 등급 을 도출한 후 0-4단계로 등급구분을 하고 있다.

본 연구에서도 경관관리가 필요한 지역과 경관변 화에 민감한 지역을 분석하여 등급을 구분하고 등 급에 따른 관리방향을 결정할수 있도록 표 1 과 같은 의사결정 매트릭스를 작성하였다. 예를 들어, 경관 관리요구도가 “하” 이면서 민감도도 “상” 인 지역을 1 등급 보전지역으로, 보전가치가 높고 경관을 보전 해야 하는 지역으로 의사결정을 할 수 있다.

1 등급 지역은 보전가치가 높고 우수한 산림경관 이 있거나 법적 보전용도의 산림구역을 의미한다. 2 등급과 3 등급 지역은 완충지역으로 보전구역을 보 전하기 위한 적정구역을 말한다. 2 등급은 현재의 경 관을 유지해야 하지만 3 등급은 부분적으로 현재 경 관을 유지하되, 경관개선을 위한 디자인이나 관리 를 소극적으로 허용할 수 있으며 전이지역 4 등급은 현재 경관을 개선하기 위해 적극적인 관리가 필요 한 지역이다(표 2).

\section{(2) 경관관리요구도(Landscape Priority Zone) 분석기준}

미국 산림청(USDA FS, 1973; 1974), 캐나다 브 리티쉬 콜롬비아주(British Columbia, 1981; 1996; 1997), 호주 타즈매니아 주(Forestry Commission of Tasmania, 2006)의 경우, 경관의 관리가 얼마 나 필요한지 세분화 하고 경관관리를 요구하는 정 도에 따라 선택 · 집중하여 관리하기 위해 경관관리 요구도를 분석하고 있다. 우리나라 산림청의 경우 에도 경관관리 강도를 결정하기 위해 GIS를 활용하 여 경관관리요구도를 분석하도록 하고 있다(이관규 등, 2008; 2009; 2010; 2011; 산림청, 2011b) 
표 2. 산림경관관리 등급별 관리방향 설정

\begin{tabular}{|c|c|c|}
\hline 구 분 & \multicolumn{2}{|c|}{ 특 징 } \\
\hline 보전(1등급) & \multicolumn{2}{|c|}{$\begin{array}{l}\text { · 경관을 보전해야 하는 특별지역 } \\
\text { · 보전가치가 높고 수려한 산림경관이 있는 지역, 법적보전용도의 산림 } \\
\text { · 개선을 필요로 하는 구역은 복원 후 보전 }\end{array}$} \\
\hline 완충(2등급) & $\begin{array}{l}\text { ·현재의 경관특성을 유지해야 하는 지역 } \\
\text { ·보전지역과 연결될 수 있도록 네트워크화 }\end{array}$ & \multirow{2}{*}{ · 보전구역을 보전하기 위해 필요한 적정구역 } \\
\hline 완충(3등급) & $\begin{array}{l}\text { · 부분적으로 현재의 경관을 유지하되 과도한 경관 } \\
\text { 디자인이나 관리를 지양해야 하는 지역 }\end{array}$ & \\
\hline 전이(4등급) & \multicolumn{2}{|c|}{$\begin{array}{l}\text { · 현재 경관을 개선하기 위해 적극적인 관리가 필요한 지역 } \\
\cdot \text { 보전 및 완충구역의 보전을 전제로 인위적인 경관자원 활용이 가능한 구역 } \\
\text { · 도로에 의한 산림경관변화지역의 복원 및 보전 }\end{array}$} \\
\hline
\end{tabular}

표 3. 사례연구 대상지에 적용한 경관관리요구도 분석 기준

\begin{tabular}{|c|c|c|c|}
\hline \multirow{2}{*}{ 분석항목 } & \multirow{2}{*}{ 대상지 적용 } & \multicolumn{2}{|c|}{ 분석방법과 기준 } \\
\hline & & 방 법 & 평점기준 \\
\hline 조망에서부터의 거리 & · 조망점 24 개소 & $\begin{array}{l}\text { 조망점과 가까운 정도를 분석 } \\
\text { 하여 0 3점으로 환산 }\end{array}$ & - (3)가까움 (0)거리가 멂 \\
\hline $\begin{array}{c}\text { 주요 경관자원으로부터 } \\
\text { 의 거리 }\end{array}$ & $\begin{array}{l}\text { ·주요능선, 전망대, 각각의 콘도, } \\
\text { 컨벤션 호텔을 주요 조망경관 } \\
\text { 자원으로 분석 } \\
\text { ※조망점으로 선정된 지역은 중복 } \\
\text { 분석하지 않음 }\end{array}$ & \multirow{2}{*}{$\begin{array}{l}\text { · 주요능선, 전망대 등의 경관자 } \\
\text { 원과 가까운 정도를 분석하여 } \\
0 \sim 3 \text { 점으로 환산 } \\
\text { · 전체 경관자원별로 분석하여 } \\
\text { 모두 합산한 후 환산 }\end{array}$} & \multirow[t]{2}{*}{ - (3)가까움 (0)거리가 멂 } \\
\hline $\begin{array}{c}\text { 이용빈도가 높고 산림에 } \\
\text { 미치는 영향요인이 있는 } \\
\text { 지역 }\end{array}$ & $\begin{array}{l}\text { · 도로변, 로프웨이, 골프장, } \\
\text { 기타 시설물 }\end{array}$ & & \\
\hline
\end{tabular}

자료: USDA FS, 1968; 1973; 1974; British Columbia, 1981; 1996; 1997; 2008; Forestry Commission of Tasmania, 2006; 이관규와 박찬우, 2012 의 내용을 종합분석하여 본 연구의 목적과 취지에 부합하도록 수정, 보완하여 기준을 설정함

본 연구에서도 구역별 경관관리요구도가 높은 곳 을 도출하기 위해 조망점으로부터의 거리, 주요 경 관자원으로부터의 거리, 이용빈도가 높은 산림지역 을 분석항목으로 설정하였다. 조망점으로부터의 거 리의 범위를 고려하여 점수를 부여하였다. 주요 경 관자원으로부터의 거리는 주요 능선, 전망대, 콘도 등 사람들의 이용빈도가 높은 곳을 선정하였고 이 용빈도가 높은 산림에 미치는 영향요인이 있는 지 역은 산림경관을 위해시킬 우려가 있는 도로변, 스 키 로프웨이, 골프장 등의 기타 인공시설요인을 분 석항목으로 선정하였다. 각 항목별 거리값을 산정 하여 최소값과 최대값의 범위를 고려하여 0-3점의 점수를 부여하였다(표 3).

\section{(3) 시각적 민감도(Visual Sensitivity) 분석기준}

시각적으로 민감한 산림의 경관 변형은 시각적으 로 두드러져서 쉽게 경관영향을 인지하게 된다. 그
러므로 시각적으로 민감한 지역은 보전위주의 관리 를, 민감하지 않은 지역은 인위적 경관변화를 허용 하는 관리방향을 설정할 수 있다(British Columbia, 1981; 1996; 1997; USDA FS, 1995; 임승빈, 2009; 이관규와 박찬우, 2012). 본 연구에서도 GIS데이터 수급이 가능한 인자 중 표고, 경사, 향, 식생, 인공 경관요소, 조망빈도를 민감도 분석 항목으로 선정 하여 적용하였다(표 4).

표고와 경사도가 높아지면 시각적으로 두드러지 면서 민감도가 높아지고 남향이고 식생밀도가 높으 면서 단조로우면 시각적으로 쉽게 노출되어 민감도 가 높아진다. 도로, 건물, 골프장과 같은 인공시설 물 주변은 이미 경관변화가 있던 곳이므로 시각적 민감도가 낮아지지만, 조망빈도가 높은 결절점이나 전망요소들에서는 시각적으로 우세하여 민감도가 높아진다. 이러한 측면을 반영하여 각 분석항목별 
표 4. 사례연구 대상지에 적용한 시각적 민감도 분석 기준 설정

\begin{tabular}{|c|c|c|c|}
\hline \multirow{2}{*}{$\begin{array}{l}\text { 분석 } \\
\text { 항목 }\end{array}$} & \multirow{2}{*}{ 대상지 적용 } & \multicolumn{2}{|c|}{ 분석방법과 기준 } \\
\hline & & 방 법 & 평점기준 \\
\hline 표고 & · 표고가 높을수록 민감도가 높음 & $\begin{array}{l}\text { · 대상지의 표고 범주를 분석하여 0 3점 } \\
\text { 으로 환산 }\end{array}$ & · (3)최고 표고 (0)최저 표고 \\
\hline 경사 & - 경사가 높을수록 민감도가 높음 & $\begin{array}{l}\text { - 대상지의 경사도 범주를 분석하여 } 0 \sim 3 \\
\text { 점으로 환산 }\end{array}$ & · (3)최고 경사 (0)최저 경사 \\
\hline 향 & · 남향일수록 민감도가 높음 & $\begin{array}{l}\text { - 남향에 가까운 정도를 분석하여 0 3점 } \\
\text { 으로 환산 }\end{array}$ & $\begin{array}{l}\text { · (3)남향에 가까움 } \\
\text { (0)남향에서 거리가 멂 }\end{array}$ \\
\hline \multirow[t]{2}{*}{ 식생 } & $\begin{array}{l}\text { · 수관층 형성 식생밀도가 고밀도이 } \\
\text { 거나 저밀도일 때 민감도가 높음 }\end{array}$ & $\begin{array}{l}\text { · 수관밀도를 분석하여 상(3), 중(2), 하(1) } \\
\text { 로 평점 } \\
\text { · 교목의 수관점유면적이 } 50 \% \text { 이하는 } \\
\mathrm{A}(\text { 소밀도(소)), 51 79\%는 } \mathrm{B} \text { (소밀도 } \\
\text { (중)), } 71 \% \text { 이상은 } \mathrm{C}(\text { 소밀도(밀) })\end{array}$ & $\begin{array}{l}\cdot(3) \text { 수관밀도 } \mathrm{A}(\text { 소 }) \\
\cdot(2) \text { 수관밀도 } \mathrm{C}(\text { 밀 }) \\
\cdot \text { (1) 수관밀도 B(중) }\end{array}$ \\
\hline & - 식생이 단조로울수록 민감도가 높음 & $\begin{array}{l}\text { 임상도를 분석하여 단순, 혼효림의 수준 } \\
\text { 을 상(3), 중(2), 하(1)로 평점 }\end{array}$ & $\begin{array}{l}\cdot(3) \text { 인공림 } \\
\cdot(2) \text { 무림목지 } \\
\cdot(1) \text { 혼효림 }\end{array}$ \\
\hline $\begin{array}{l}\text { 인공경관 } \\
\text { 요소 }\end{array}$ & $\begin{array}{l}\text { ·도로, 건물, 골프장, 기타 시설물과 } \\
\text { 멀수록 민감도가 높음 }\end{array}$ & $\begin{array}{l}\text { ·도로, 건물, 골프장, 기타 시설물과 가까 } \\
\text { 운 정도를 분석하여 } 0 \sim 3 \text { 점으로 환산 }\end{array}$ & · (3)거리가 멂 (0)가까움 \\
\hline $\begin{array}{l}\text { 조망빈도 } \\
\text { (시각적 } \\
\text { 노출) } \\
\end{array}$ & $\begin{array}{l}\text { - 시각적 노출 조망빈도가 높을수록 } \\
\text { 민감도가 높음 }\end{array}$ & $\begin{array}{l}\text { 조망점별 가시권역을 분석하여 모두 합 } \\
\text { 산함으로써 조망빈도를 산출하고 그 범 } \\
\text { 주를 0 3점으로 환산 }\end{array}$ & $\begin{array}{l}\text { · (3)조망빈도가 높은 지역 } \\
\text { (0)조망빈도가 낮은 지역 }\end{array}$ \\
\hline
\end{tabular}

자료: British Columbia, 1981; 1996; 1997; USDA FS, 1995; Forestry Commission of Tasmania, 2006; 이관규 등, 2009; 2010; 2011; 임승빈, 2009; 이관규와 박찬우, 2012의 내용을 종합분석하여 본 연구의 목적과 취지에 부합하도록 수정, 보완하여 기준을 설정함

분석값을 등분하여 상, 중, 하로 구분하였다.

\section{3. 산림기능별 산림경관 관리등급 고찰}

지속가능한 산림자원 관리지침(산림청, 2012)에 따르면 산림의 기능은 목재생산림, 수원함양림, 산 지재해방지림, 자연환경보전림, 산림휴양림, 생활 환경보전림으로 구분된다. 본 연구에서는 산림기능 별 산림경관등급을 구분하여 경관관리 방향을 설정 할 수 있도록 고찰하였다.

\section{4. 연구대상지와 특성}

연구대상지로 강원도 정선군 고한읍 일대 약 $3,070 \mathrm{ha}$ 에 대하여 분석하였다(그림 1). 대상지 내 에는 고한읍내 주거지와 상업지역이고 주요 산림은 백운산 일대의 일부로 그 내부에는 강원랜드, 하이 원 리조트 골프장과 스키장 시설, 과거에 운영하던 채석장 등이 입지하고 있다.

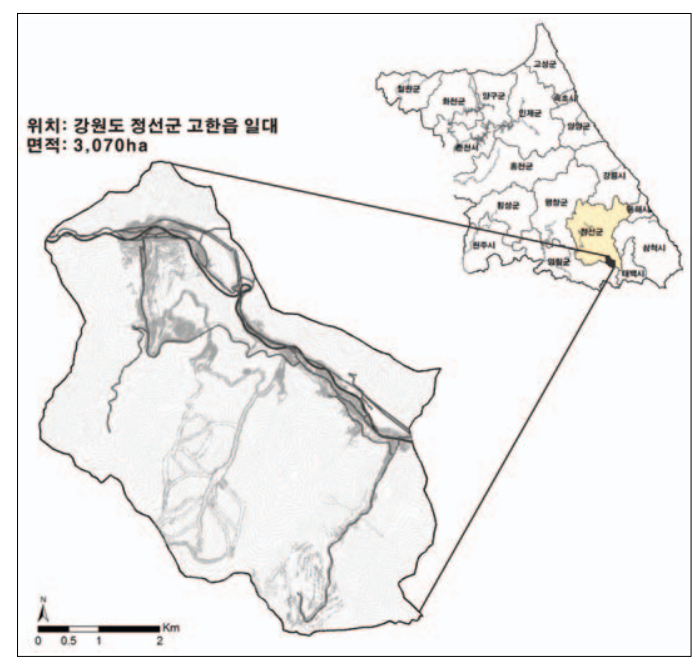

그림 1. 대상지 개요

해발 약 $1,000 \mathrm{~m}$ 이상의 고지대가 주를 이루고 있고(그림 2c), 북향이 약 $34.72 \%$ 로 주 향을 이루 고 있고(그림 $2 \mathrm{~d}$ ), 주로 활엽수림이 약 $46.34 \%$, 침 활혼효림이 약 $18.5 \%$, 낙엽송림이 약 $16.71 \%$ 를 보 이고 있다(그림 2f). 대경목이 약 $47.13 \%$ 를 차지하 며(그림 $2 \mathrm{~g}$ ), 영급은 4 영급이 대상지의 약 $33 \%$ 로 


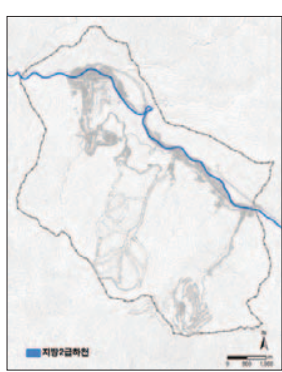

a. 하천

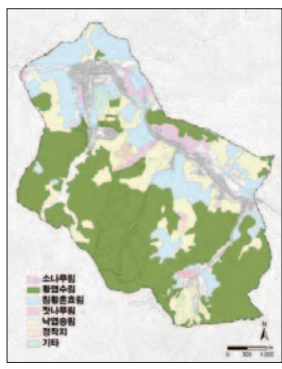

f. 임상

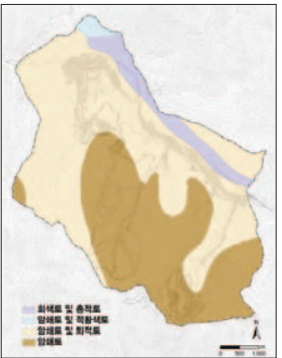

b. 토양

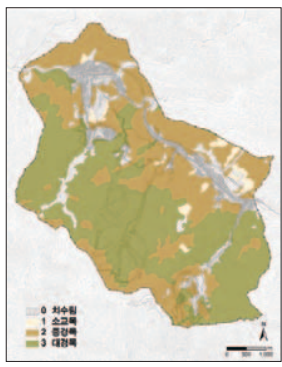

g. 경급

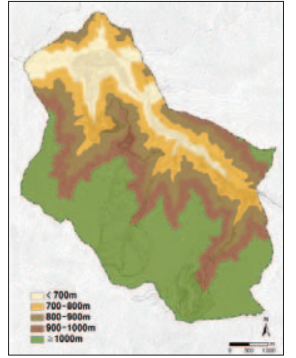

c. 표고

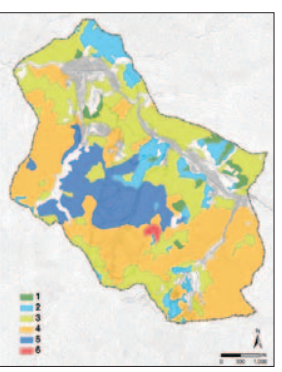

h. 영급

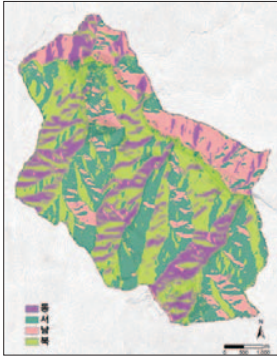

d. 향

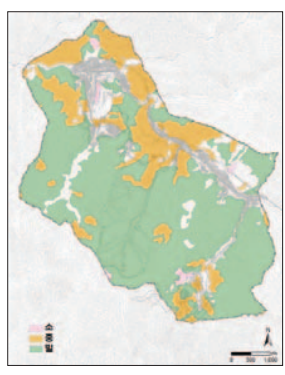

i. 임상밀도

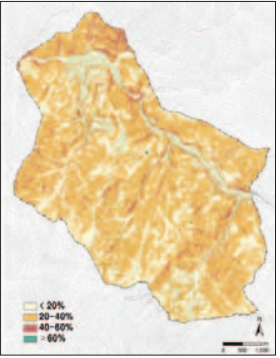

e. 경사

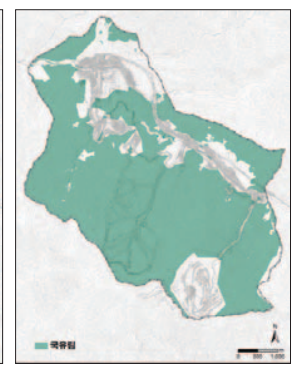

j. 국유림

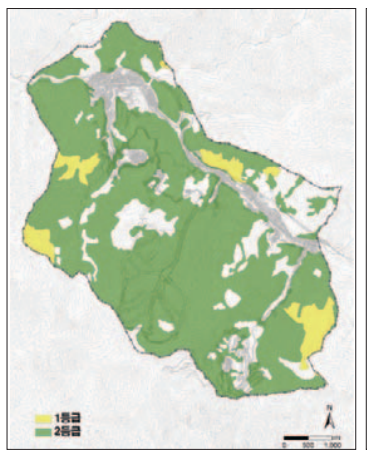

k. 생태자연도

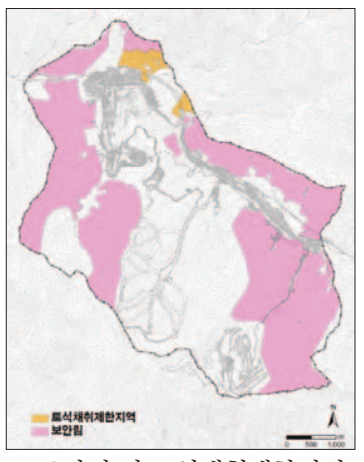

1. 보안림 및 토석채취제한지역

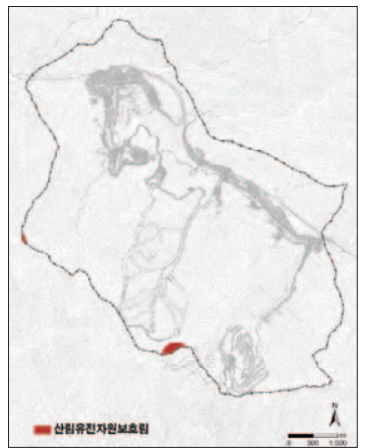

$\mathrm{m}$. 산림유전자원보호림

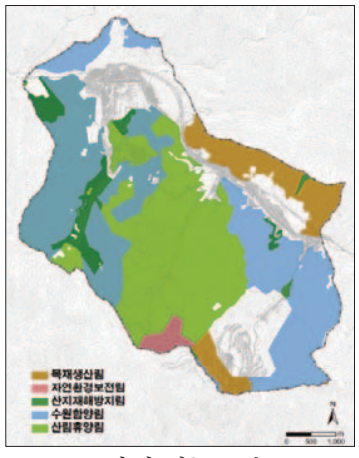

n. 산림 기능구분도

그림 2. 대상지 현황과 연구재료

가장 높은 비율을 나타내고 있다(그림 2h), 교목의 수관점유 면적 비율을 나타내는 밀도 중 '밀' 이 약 $62.7 \%$ 로 가장 높은 비율을 나타내고 있다(그림 2i). 대상지의 약 $74.3 \%$ 가 국유림이고(그림 $2 \mathrm{j}$ ), 생태자 연도 2 등급이 약 $70.53 \%$ 로 높은 비율을 차지하고 있다(그림 $2 \mathrm{k}$ ). 보안림은 약 $40.9 \%$ 의 비율을 차지 하고 있고(그림 21), 토석채취제한지역은 약 $1.5 \%$ 로 낮은 점유율을 나타내고 있다(그림 21).

산림유전자원보호림은 약 $0.23 \%$ 로 가장 낮은 점 유율을 나타내고 있고(그림 $2 \mathrm{~m}$ ), 산림기능구분은 전체 중 산림휴양림이 약 $66.85 \%$ 로 가장 높은 비율 을 나타내고 있고 다음으로 수원함양림이 약
$39.21 \%$ 를 차지하고 있다(그림 $2 \mathrm{n}$ ).

\section{5. 연구재료}

경관관리요구도와 시각적 민감도를 분석하기 위 해 주로 산림청 FGIS데이터를 활용하였다. 대상지 내 산림의 기능과 현황을 파악하기 위해 동부지방 산림청에서 제공한 FGIS 중 국유림 관계, 임상도, 보안림, 토석채취제한지역, 산림유전자원보호림, 산림기능구분도(자연환경보전림, 산지재해방지림, 산림휴양림, 목재생산림, 수원함양림), EGIS의 생 태자연도를 활용하였다. 강원랜드에서 제공한 $1 / 5,000$ 수치지형도를 사용하여 수치고도모델 


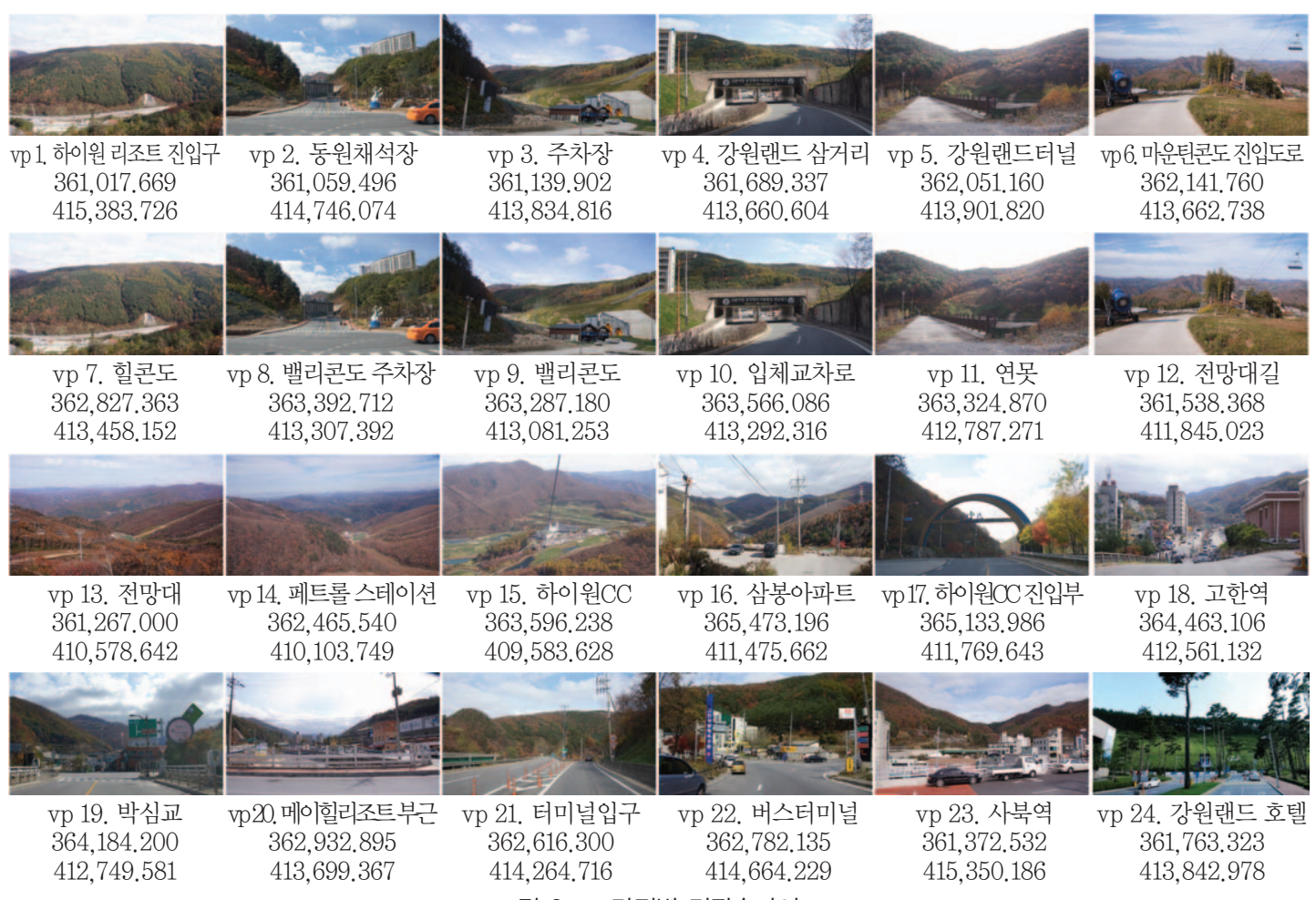

(Digital Elevation Model, DEM)을 구축하였고 이를 활용하여 표고, 경사, 향을 분석하였다. $\mathrm{DEM}$ 구축을 위해 수치지도를 가공하고 도로와 리조트시 설, 기타 인공시설을 추출하기 위해 AutoCAD 2009를 활용하였다.

\section{III. 결과 및 고찰}

\section{1. 산림경관 관리등급 도출}

조망점 선정기준에 따라 산림이 다수 조망되는 지점을 선별하여 총 24 개의 조망점을 설정하였다 (그림 3, 4). 24개의 조망점을 기준으로 대상지내 산림일대로의 조망수요를 분석하고 경관관리가 더 욱 요구되는 지역을 선별하고자 내·외부에 고루 선정하였다. $12,13,14,15$ 번 조망점은 산림경관자 원 내부에 설정한 것으로 결절점, 콘도, 정상부 등 내부에서 외부로 바라볼 때의 산림경관을 파악하기

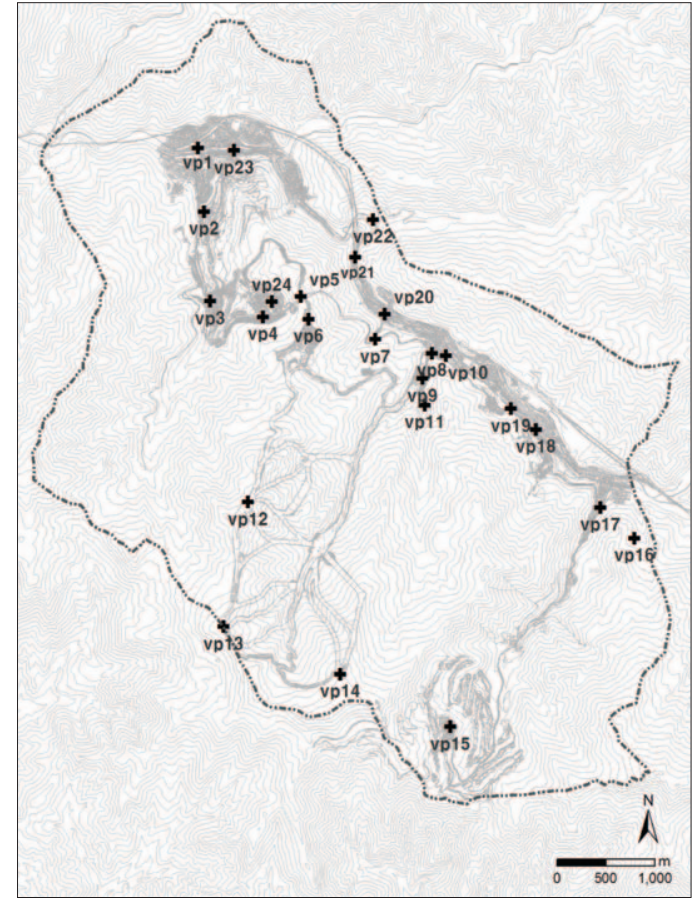

그림 4. 조망점 선정 결과 위해 설정한 것이다. 그 외의 조망점은 고한읍내나 
하이원 리조트 진입로에 설정한 조망점으로, 주요 산림경관자원이 보이는 결절점, 진입로, 전망대 등 이 이에 해당하였다.

총 24 개 조망점을 활용하여 조망점에서의 경관관 리요구도와 시각적민감도를 도출하고 최종 산림경 관 관리등급을 구분하였고 그 결과는 그림 3 과 같다.

\section{(1) 경관관리요구도}

이용빈도가 높은 지점으로써 도로, 기타 인공시 설과의 인접성을 점수화하고(그림 5) 각 인자별 점 수를 종합한 후 최종 경관관리요구도를 상, 중, 하 구역으로 도출하였다(그림 6). 분석 결과, 경관관리 도 “상”지역은 주로 도로나 하천변, 시가화지역으 로, 적극적인 경관관리를 통해 경관개선이 필요한 곳이다. 경관관리요구도 “중” 지역은 중산간지역으 로 로프웨이와 하이원 리조트 골프장이 입지하였으 므로 인위시설로 인해 훼손된 경관을 복원하기 위 한 관리방안이 필요하다. 경관관리요구도 "하" 지역

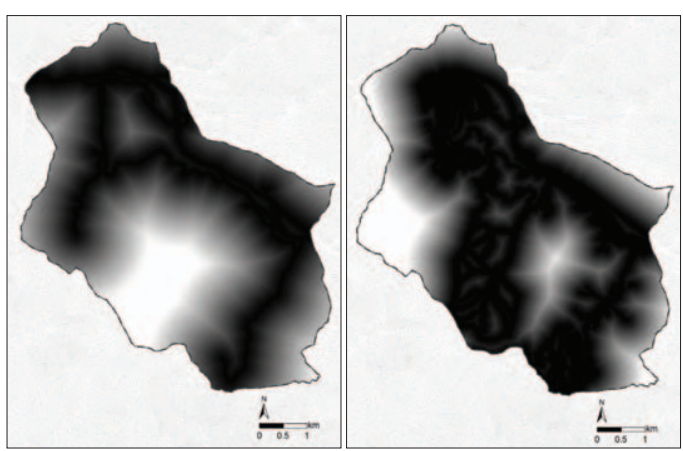

a. 도로

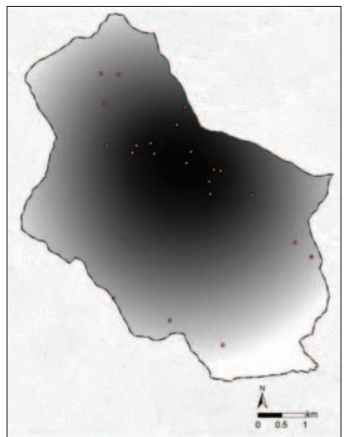

c. 조망점 b. 기타 인공시설

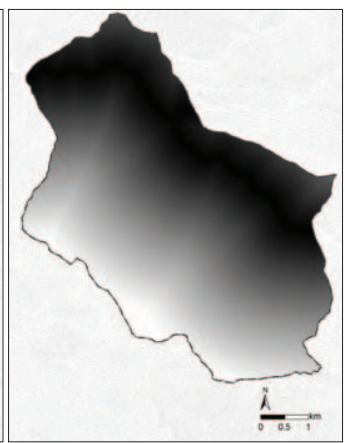

d. 지방하천 2급
그림 5. 경관관리 요구도 분석인자별 분석결과 범례: 0

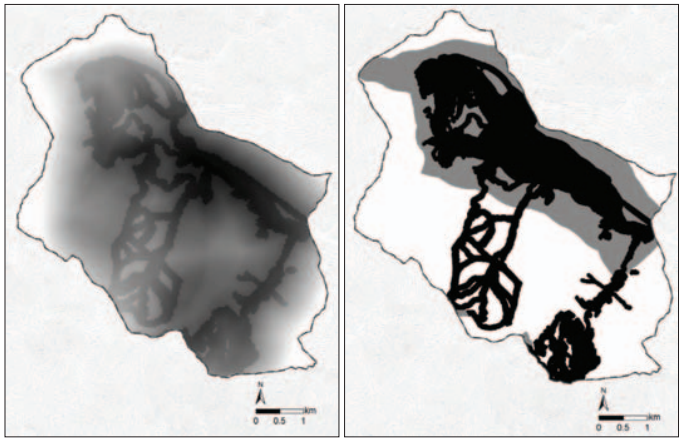

a. 중첩결과

b. 등급구분 결과

그림 6 . 경관관리 요구도 분석 결과

범례: a:

은 그 외 고지대 산림으로, 현재의 우수한 경관을 보전 관리를 하는 것이 바람직하다.

\section{(2) 시각적 민감도}

가시권분석, 경사, 표고, 향, 임상, 수관밀도를 분 석하여 시각적 민감도를 도출한 결과(그림 7), 시각 적 노출 조망빈도가 높을수록 민감도가 높은 것으 로 나타났다(그림 8). 가시권역(그림 $7 \mathrm{a}$ )과 경사가 높은 능선과 애추경관이 발달한 급경사지 일대가 민감도가 높았고(그림 $7 \mathrm{~b}$ ), 표고가 높은 스키장 정 상일대 등(그림 $7 \mathrm{c}$ ), 남향에 가까운 지역(그림 $7 \mathrm{~d}$ )이 민감도가 높은 것으로 나타났다. 식생분야에서는 임상이 다양한 지역(그림 $7 \mathrm{e}$ ), 수관밀도가 높은 지 역(그림 $7 f$ )이 민감도가 높은 것으로 나타났는데, 각 지역은 주로 시가지일대 보다는 산간지역이 이 에 해당하였다. 인공경관요소는 도로를 기준으로 분석하였고(그림 $7 \mathrm{~g}$ ) 그 결과, 스키장 부근의 산림 지대가 민감도가 높은 것으로 분석되었다.

종합 분석결과, 시가화 지역을 제외한 대부분의 고지대 산림지역은 시각적 민감도가 높은 것(상)으 로 나타났고, 개발의 영향이 적은 산림은 작은 영향 에도 시각적으로 두드러졌다. 민감도 “중” 지역은 산간 지역 중 로프웨이 일대로, 주변 산림의 민감도 는 높지만 로프웨이의 입지로 인해 민감도가 다른 산림보다 감소되었다. 민감도 “하” 지역은 고한읍 시가지 일대로 경관변화에 거의 민감하게 반응하지 않는 지역으로 적극적인 경관관리 도입이 가능하다. 


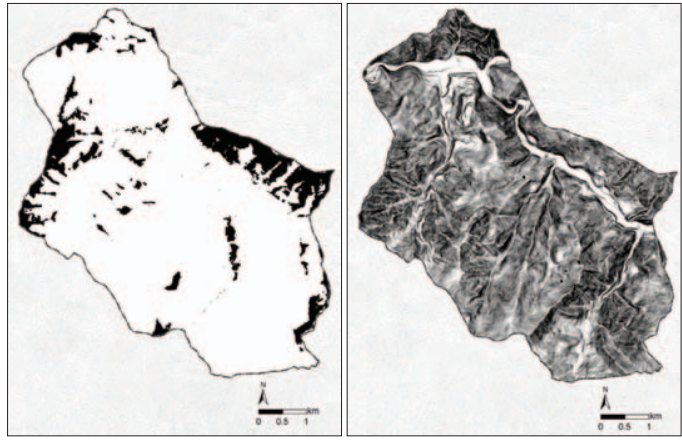

a. 가시권분석

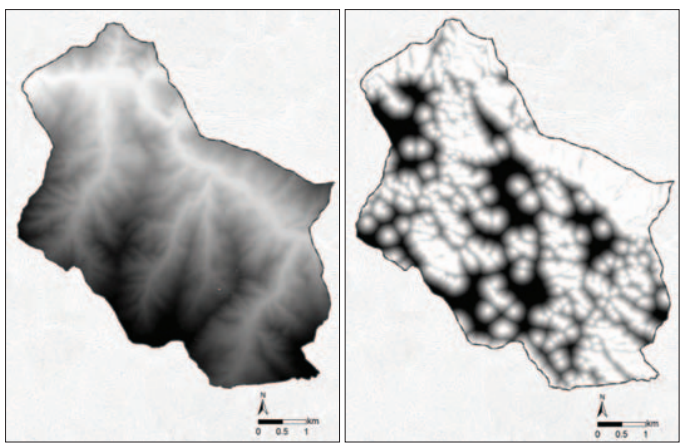

c. 표고

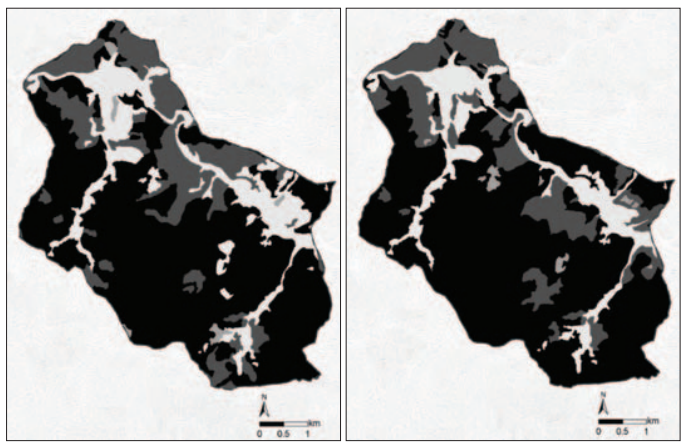

e. 식생(임상)

f. 식생(수관밀도)

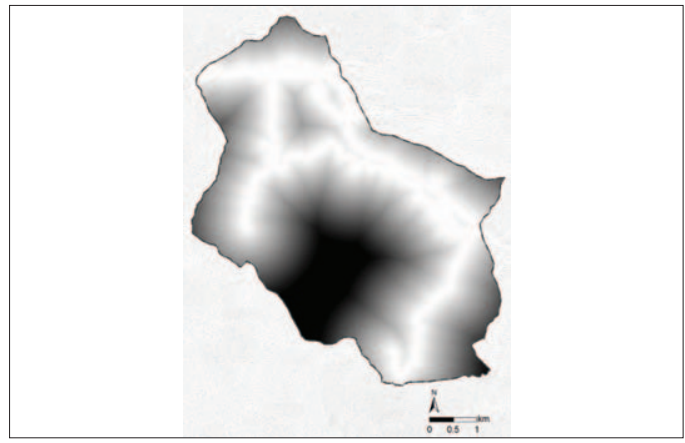

g. 도로

그림 7. 시각적 민감도 분석인자별 분석결과

범례: $\mathrm{a}, \mathrm{b}, \mathrm{c}, \mathrm{d}, \mathrm{g}: 0 \square 3$

e, f: $\square 3, \square 2, \square 1, \square 0$

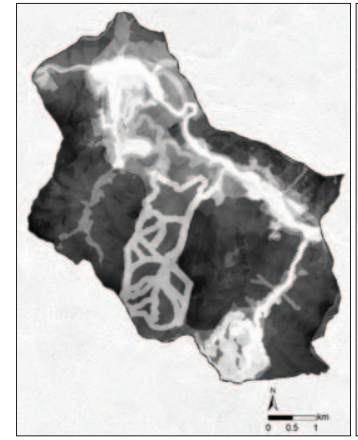

a. 중첩결과

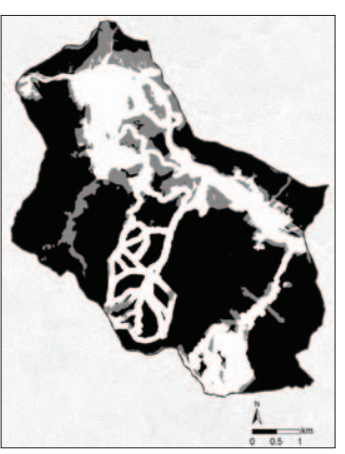

b. 등급구분 결과

그림 8. 시각적민감도 분석 결과
(3) 산림경관 관리등급

경관관리요구도 상, 중 하 구분 결과와 시각적 민 감도 상, 중, 하 구분 결과를 중첩한 결과는 그림 9 와 같다. 요구도가 “상” 이고 민감도가 “하" 인 지역 (4등급)은 하이원 리조트와 스키장 로프웨이 그리고 그 주변이 대부분으로 분석되었다. 이를 제외한 대 부분의 산지지역으로 현재의 경관을 보전하면서도 개선이 필요로 하는 구역은 복원 후 보전해야 하는

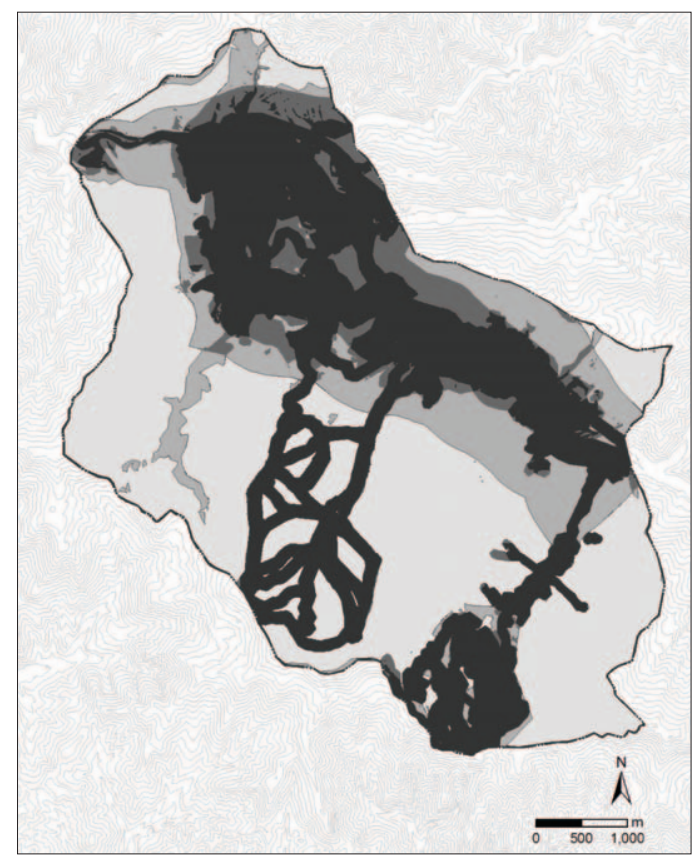

그림 9. 산림경관 관리등급도

범례: $\square$ 1등급, $\square 2$ 등급, $\square$ 3등급, $\square$ 4등급 
등급으로 도출되었다.

2 등급은 고한읍내 하천 양안 약 $500 \mathrm{~m}$ 의 지역과 서쪽의 강원호텔 부근 인공시설 일대로 도출되었 다. 인공시설 지역지만 그 입지 규모가 상대적으로 작고 주변 산림경관 상태가 양호하여 2등급으로 분 석된 것으로 판단된다. 3 등급 지역으로 고한읍내에 근접한 산림과 읍내 내의 산림이 포함되었다. 부분 적으로 현재 경관을 유지하되 과도한 개선사업은 지양해야 한다. 4 등급 지역으로는 마을, 상가, 도로 등과 하이원 리조트와 스키장 로프웨이 등 대부분 의 인공시설지역이 이에 포함되었다. 인위시설로 인해 훼손된 경관을 복구하기 위한 적극적인 개선 관리 사업이 필요하다.

종합분석 한 결과를 4 개의 등급으로 나타낸 결과 는 어느 정도의 관리 강도가 필요한지를 나타내고 있으므로 이에 따른 등급별 관리 방향에 대한 의사 결정을 할 수 있다.

\section{2. 산림기능별 산림경관 관리방안}

\section{(1) 자연환경보전림}

보호할 가치가 있는 생태 - 문화 - 역사 - 경관 · 학술적 가치가 높은 산림자원의 보전이 필요한 산 림으로 대상지 내 자연환경보전림은 $1.3 \%$ 를 차지하 고 있고 주로 리조트 상단부 지역에 위치하고 있다. 자연환경보전림 내 경관관리 지역은 모두 스키장 정상부근으로 1 등급 지역은 $57.05 \%, 2$ 등급 지역은 $3.98 \%, 3$ 등급 지역은 $1.57 \%, 4$ 등급 지역은 $37.40 \%$ 를 차지하는 것으로 나타났다. 1 등급은 법 적보호지역 등 생태계, 유전자원 보호 등을 위해 보 전해야할 산림으로 다층혼효림을 주 관리대상으로 유지관리, 2 등급은 역사 · 문화적 가치 보호 등을 위 해 보전해야할 산림으로 자생종자나 어린나무를 묘 목으로 조림, 골라베기로 수확 - 관리, 3 등급은 병충 해 예방, 4 등급은 보호울타리 등 보호시설 설치를 통한 산림 이용 - 관리가 필요하다.

\section{(2) 산지재해방지림}

산사태, 토사유출, 대형산불, 산림병해충 등 각종
산림재해에 강한 산림이면서 산림재해의 방지 및 임지의 보전에 필요한 산림을 말한다. 대상지 내 산 지재해방지림은 $4.3 \%$ 를 차지하고 있고 하이원 골 프장 진입부와 강원랜드 터널이 위치한 곳에 분포 하는 것으로 나타났다. 산지재해방지림 내 경관관 리 1 등급 지역은 서쪽에 강원랜드 진입도로 부근 산 림으로 $43.20 \%, 2$ 등급 지역은 스키장 로프웨이의 서쪽 하이원길 부근으로 $30.88 \%$, 3등급 지역은 2 등급 지역의 일부로 $5.44 \%, 4$ 등급 지역은 읍내 부 근과 하이원 리조트 부근 산림의 일부로 $20.48 \%$ 를 차지하고 있다. 1 등급은 대형 산불이나 산사태 등이 우려되는 침엽수 단순림을 집중 관리, 2 등급은 침엽 수림은 솎아베기를 통해 다층혼효림으로 유도, 3 등 급은 속성수를 혼합하여 혼효림으로 조림시행, 4 등 급은 숨의 활력이 회복될 때까지 약도의 솎아베기 를 5년 내외의 간격으로 수회 실시하여 산사태, 수 해, 풍해, 설해 등 예방하는 것이 필요하다.

\section{(3) 산림휴양림}

수목 · 야생동물 - 계곡 등 산림이 가지고 있는 아름다운 자연풍경을 파괴시키지 않고 국민의 정신 순화, 오락 및 휴식처로 제공하기 위하여 지정한 일 정 지역의 산림을 말한다. 산림휴양림은 $49.6 \%$ 를 차지하고 있고 주로 하이원 리조트를 포함한 스키 슬로프 지역, 백운산 지역에 위치하고 있다. 산림휴 양림 내 경관관리 1 등급 지역은 스키장이 입지한 산 림으로 $55.31 \%, 2$ 등급 지역은 스키장 로프웨이의 서쪽 하이원길 부근으로 $11.31 \%$, 3등급 지역은 고 한읍내 일부로 $4.46 \%, 4$ 등급 지역은 스키장 로프웨 이와 고한읍내 중앙부분으로 $28.93 \%$ 를 차지하는 것으로 나타났다. 1 등급은 천연림, 희귀식물, 노령 목, 괴목(怪木), 노령고사목 등을 보전, 2 등급은 생 태적 활력도 제고를 위한 솎아베기 등 숲가꾸기를 통한 보전관리, 3 등급은 경관수종이나 지역특색이 있는 수종 등으로 조림을 통한 공간 이용관리, 4 등 급은 시설부지, 등산로, 산책로 주변으로부터 가시 권을 고려하여 $30 \mathrm{~m}$ 이내 지역은 공간이용 및 관리 하는 것이 필요하다. 


\section{(4) 목재생산림}

생태적 안정을 기반으로 하여 국민경제 활동에 필요한 양질의 목재를 지속적·효율적으로 생산 · 공급하기 위한 산림을 말한다. 대상지 내 목재생산 림은 $8.3 \%$ 를 차지하고 있고 고한역과 고등학교 일 대 마을 인근산림지역에 위치하고 있다. 목재생산 림 내 경관관리 1 등급 지역은 고원고등학교 일대 산 림 정상부와 리조트 정상부로 $18.76 \%, 2$ 등급 지역 은 고한고등학교 일대 산림 중산간 지역으로 $36.18 \%, 3$ 등급 지역은 고한고등학교와 대원아파트 입지지역 일대로 $20.05 \%$, 4등급 지역은 리조트 정 상부와 도로변 산림으로 $25.01 \%$ 를 차지하는 것으 로 나타났다. 1 등급은 주로 요존국유림, 천연림을 중심으로 보전, 2 등급은 숲가꾸기, 조림을 통한 전 반적인 보전관리, 3 등급은 보조적 목재생산재로 활 용할 수 있는 부수종과 일반소경재의 조림 · 숲가꾸 기 등을 통한 공간활용 - 관리, 4 등급은 마을, 도로, 농경지 인접지역 산림 내 참나무류 등 내화수종 관 리가 필요하다.

\section{(5) 수원함양림}

공공용수의 원활한 공급 및 한수해(旱水害)의 방 지를 목적으로 설정된 산림을 말한다. 대상지 내 수 원함양림은 $39.1 \%$ 를 차지하고 있고 강원랜드 및 리 조트의 주요 지역을 제외한 나머지 지역에 고루 분 포하는 것으로 나타났다. 수원함양림 내 경관관리 1 등급 지역은 리조트 골프장과 스키장일대 산림을 제외한 산림으로 $62.32 \%, 2$ 등급 지역은 하이원 리 조트 골프장 진입부근 산림과 사북역과 강원호텔 부근 산림일대로 $19.62 \%, 3$ 등급 지역은 고한읍내 일부지역으로 $4.06 \%, 4$ 등급 지역은 고한읍내 일부 와 스키장 인접산림의 일부로 $14.01 \%$ 를 차지하고 있다. 1 등급은 약해(藥害)가 발생하지 않도록 숲가 꾸기를 시행, 집수유역 안의 지역의 경우 약제사용 최소화, 덩굴제거, 수관울폐도 50-80\% 수준을 유 지할 필요가 있고 2 등급은 수원함양기능 증진을 위 한 천근성 수종이 혼합되도록 조림관리, 3 등급은 솎 아베기를 5 년 내외로 실시하고, 4 등급은 솎아베기 를 5 년 내외로 실시하고 골라베기를 한다. 골라베기

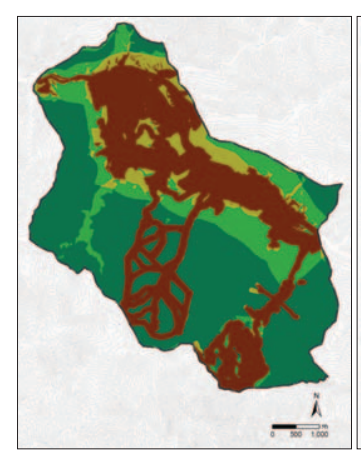

a. 관리등급도

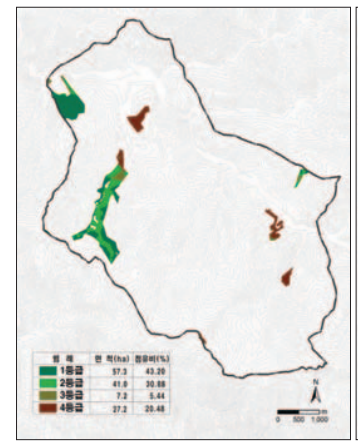

c. 산지재해방지림

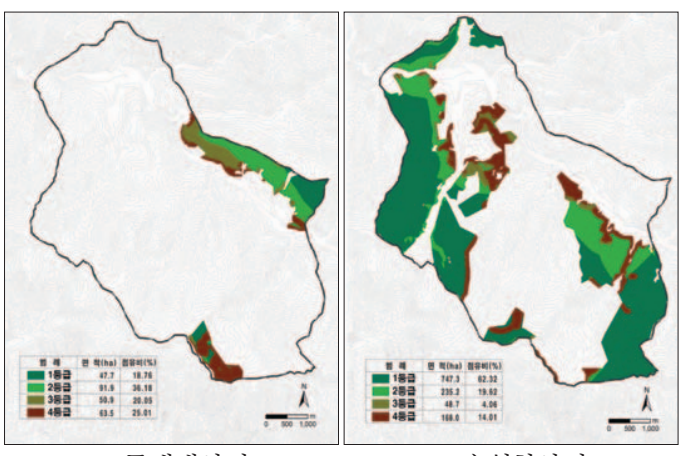

e. 목재생산림

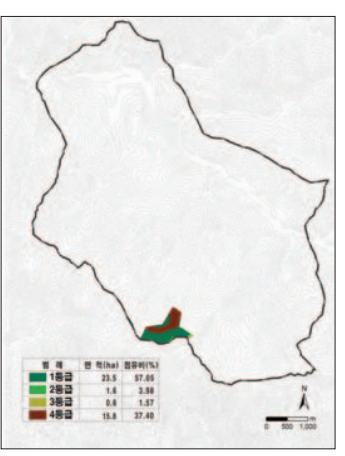

b. 자연보호환경보전림

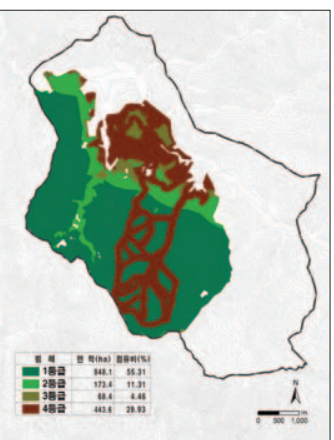

d. 산림휴향림

f. 수원함양림
그림 10. 산림기능별 산림경관 관리등급 분석 결과

범례: $\square$ 1등급, $\square 2$ 등급, $\square 3$ 등급, $\square$ 4등급

가 불가피할 경우 벌채구역을 $2 \mathrm{ha}$ 미만으로 모두베 기와 모수작업(母樹作業)이 필요하다.

\section{IV. 결 론}

본 연구는 산림경관 관리를 위한 관리등급 설정 기법을 개발하고 산림기능별 관리방안을 제공하고 자 하였고 현장적용을 통하여 기법의 타당성을 입 증하고자 하였다. 현장적용 결과, 산림내부와 인근 
지역의 토지이용별로 등급이 구분된 결과를 도출할 수 있었다. 동일 산림지역이라 하더라도 토지이용 이나 산림자원의 구성에 따라 산림의 기능이 달라 지므로 관리등급 결과를 산림기능도에 중첩시켜 기 능별 관리등급을 도면화하고 관리방안을 제시하고 자 하였다.

1. 산림경관을 우선적으로 관리할 구역과 물리적 경관변화에 대한 수용력을 분석하기 위해 전망대, 콘도, 호텔 등 조망 수요가 높은 지점을 대상으로 분석한 결과를 경관관리요구도로 도출하였다. 시각 적 민감도는 경관변화에 시각적으로 민감한 구역을 선별하기 위해 시각적 흡수능, 물리적 경관 특성, 조망여건을 분석한 결과로 나타냈다. 현장적용한 결과, 이용빈도가 높은 도로와 인공시설이 경관관 리요구도에서 "상” 등급으로 도출되었고 경관상태 가 양호한 고지대 산림은 시각적 민감도 부문에서 "상" 등급으로 나타났다.

2. 산림경관 관리등급은 경관관리요구도의 3 개 등급과 시각적 민감도의 3 개 등급결과를 의사결정 매트리스를 활용하여 최종 산림경관 관리등급 결과 를 도출할 수 있었다. 관리등급 1 등급 지역은 하이 원 리조트 시설이 입지한 지점을 제외한 대부분의 산림지역, 2 등급 지역은 중산간지역, 3 등급 지역은 고한읍내 주변, 4 등급 지역은 마을, 상가, 도로 등 과 하이원 리조트 골프장과 스키장이 로프웨이가 있는 인공시설지역으로 도출되었다. 적극적인 경관 관리가 요구되는 지역은 4 등급 지역으로, 인위시설 로 인해 훼손된 경관을 복구하기 위해 적극적인 개 선관리 사업이 필요하다.

3. 산림기능별 관리방안을 설정하고자 대상지 산 림기능별 관리방안을 제시하기 위해 산림기능을 파 악하고 관리등급구분 결과를 산림기능도에 중첩하 였다. 산림이 지닌 기능 및 특성에 따라 관리 강도 의 정도를 설정하였다. 이러한 기능별 관리설정방 안을 적용함으로써 동일 등급지역이라 하더라도 산 림의 기능과 특성에 따라 각기 다른 세부적 산림경 관 관리방안설정이 가능하다는 결론을 얻을 수 있 었다.
본 연구는 산림경관관리를 위해 관리하고자 하는 산림의 경관관리 요구도와 시각적 민감도를 강원도 정선군 고한읍 하이원 리조트 일대에 현장 적용함 으로써 경관관리 구역구획하는 방법과 관리등급 구 분방법을 제시하는데 중점을 두고 진행되었다. 향 후 숲가꾸기, 조림, 벌채 등 기존의 산림관리사업이 산림경관관리를 고려한 사업이 될 수 있도록 연계 하는 연구가 필요하다.

\section{사 사}

본 논문은 동부지방산림청 연구과제(대규모 리조트 단지(강원랜드) 경관림 조성 기본설계, 120110872)의 지원으로 작성되었습니다.

\section{참고문헌}

강미희, 김성일, 2010 , 산림경관 등급화를 위한 평가 지표 개발, 한국임학회지, 99(6), 777-784. 구자훈, 2001 , 도시조망권과 경관관리: 외국 도시의 조망권 확보 사례, 도시문제, 36(10), 34-48. 김세천, 노재현, 박재철, 허준, 1996 , 마이산도립공 원의 조망경관 특성에 관한 연구, 한국조경 학회지, 24(2), 2074-2085.

김세천, 허준, 2007 , 한라산 성판악 등산로 주변 경 관이미지 및 선호도 특성에 관한 연구. 한국 생태학회지, 21(2), 134-140.

김승주, 임승빈, 2009 , 도시경관 진단을 위한 평가 모델 및 지표개발 연구. 한국조경학회지, 37(1), 78-86.

김재준, 박찬우, 강민지, 2010 , 산림경관 방향 설정 을 위한 지자체 관리자 의식분석, 한국임학 회지, 99(4), 603-610.

박민우, 송형섭, 2003 , 안면도 자연휴양림 경관관 리를 위한 시각선호도 분석, 한국임학회지, 92(4), 313-320.

방재성, 송병화, 양병이, 2008 , 조망점의 선정기준 과 경향에 관한 연구, 한국조경학회지, 
36(1), 70-79.

산림청, 2004, 지속가능한 산림자원 관리지침. 산림청, 2011a, 산림기본통계.

산림청, 2011b, 산림경관 계획관리 업무편람. 산림청, 2012 , 지속가능한 산림자원 관리지침.

이관규 등, 2008 , 산림경관벨트 구축방안에 관한 연구. 산림청 보고서.

이관규, 이정환, 장효진, 2009 , 국가산림경관인벤 토리 작성 연구, 국립산림과학원 1차년도 보 고서.

이관규, 이정환, 장효진, 2010, 국가산림경관인벤 토리 작성 연구, 국립산림과학원 2차년도 보 고서.

이관규, 이정환, 장효진, 2011, 국가산림경관인벤 토리 작성 연구, 국립산림과학원 3차년도 보 고서.

이관규, 2011, 국립공원 집단시설지구 자연경관관 리를 위한 층고규제 합리화 방안, 한국조경 학회지, 39(5), 48-56.

이관규, 박찬우, 2012 , 시각적 질 평가에 의한 산림 경관 관리구역 구획방법, 한국임학회지, 101(1), 148-157.

임승빈, 2009 , 경관분석론, 서울대학교 출판부. 장철규, 정성관, 김경태, 2011 , 도시개발사업의 경 관평가를 위한 조망점 선정체계 구축 및 적 용, 한국조경학회지, 39(3), 39-50.

정윤희, 신지훈, 임승빈, 2002 , 계절별 경관의 시각 적 선호도, 한국조경학회지, 30(4), 19-27. 정정섭, 권상준, 조태동, 2004 , 시가지내 산악경관 관리를 위한 조망점의 수직상향 이동의 검 증, 한국환경생태학회지, 17(4), 366-374.

조용준, 이정형, 남승진, 정영덕, 홍안희, 장상근, 손 승광, 김영석, 김현숙, 강권, 박현홍, 유창 균, 이봉수, 이정림 역, 2006 , 일본의 경관 계획, 서울, 태림문화사.

최윤, 조동범, 1994, 도시주변 능선녹지를 배경으로 하는 아파트 경관 시각적 영향 -물리적 경 관변수 및 주시점 분석에 의한 다각적 접
근-, 한국조경학회지, 22(2), 81-103.

행정안전부, 문화체육관광부, 농림수산식품부, 환경 부, 국토해양부, 산림청, 2009 , 경관계획수 립지침.

허준, 김대수, 주신하, 김충식, 한명준, 2007 , 산지 훼손 유형에 따른 경관 선호의 변화, 한국조 경학회지, 35(4), 71-80.

British Columbia, 1981, Forest Landscape Handbook.

British Columbia, 1996, Clearcutting and Visual Quality: A Public Perception Study.

British Columbia, 1997, Visual Impact of Partial Cutting.

British Columbia, 2008, Recreation Manual Forest Landscape Management.

Chang, H., Li, F., Li, Z., Wang, R., Wang, Y., 2011, Urban landscape pattern design from the viewpoint of networks: A case study of Changzhou city in Southeast China, Ecological Complexity, 8(1), 51-59.

Clay, G. R. and Daniel, T. C., 2000, Scenic landscape assessment: the effects of land management jurisdiction on public perception of scenic beauty, Landscape and Urban Planning, 49(1-2), 1-13.

Daniel, T. C. and Boster, R. S., 1976, Measuring landscape esthetics: the scenic beauty estimation method, USDA Forest Service Research Paper RM-167, Fort Collins, Rock Mountain Forest and Range Experiment Station.

Forestry Commission of Tasmania, 2006, A Manual for Forest Landscape Management.

Fry, G., Tveit, M. S., Ode, A., Velarde, M. D., 2009, The ecology of visual landscapes: Exploring the conceptual common ground of visual and ecological landscape indicators, Ecological Indicators, 
9(5), 933-947.

Germino, M. J., Reiners, W. A., Blasko. B. J., Mcleod, D., Bastian, C. T., 2001, Estimating visual properties of Rocky Mountain landscapes using GIS. Landscape and Urban Planning, 53(1-4), 71-83.

Greene, R., Luther, J. E., Devillers, R., Eddy, B., 2010, An approach to GIS-based multiple criteria decision analysis that integrates exploration and evaluation phases: Case study in a forestdominated landscape, Forest Ecology and Management, 260(12), 2102-2114.

Karjalainen, E. and Tyrvainen, L., 2002, Visualization in forest landscape reference research: a Finnish perspective, Landscape and Urban Planning, 59(1), 13-28.

Meitner, M. J., 2004, Scenic beauty of river views in the Grand Canyon: relating perceptual judgments to locations, Landscape and Urban Planning, 68(1), 3-13.

Ode, A., Fry, G., Tveit, M. S., Messager, P., Miller, D., 2009, Indicators of perceived naturalness as drivers of landscape preference, Journal of Environmental Management, 90(1), 375-383.

Ripple, W. J., Bradshaw, G. A., Spies, T. A., 1991, Measuring forest landscape patterns in the cascade range of Oregon, USA, Biological Conservation, 57(1), 73-88.

USDA Forest Service, 1968, Forest Landscape Description and Inventories - a basis for landplanning and design.

USDA Forest Service, 1973, National Forest landscape management. Volume1.

USDA Forest Service, 1974, National Forest landscape management. Volume2.

USDA Forest Service, 1993, Forest Landscape Analysis and Design.

USDA Forest Service, 1995, Landscape Aesthetics: A Handbook for Scenery.

Yanar, T. A. and Akyurek, Z., 2006, The enhancement of the cell-based GIS analyses with fuzzy processing capabilities, Information Sciences, 176(8), 1067-1085.

Zube, H. E., Sell, J. L., Taylor, G. J., 1982, Landscape perception: Research, application and theory, Landscape Planning, 9(1), 1-33.

최종원고채택 13. 01. 25 